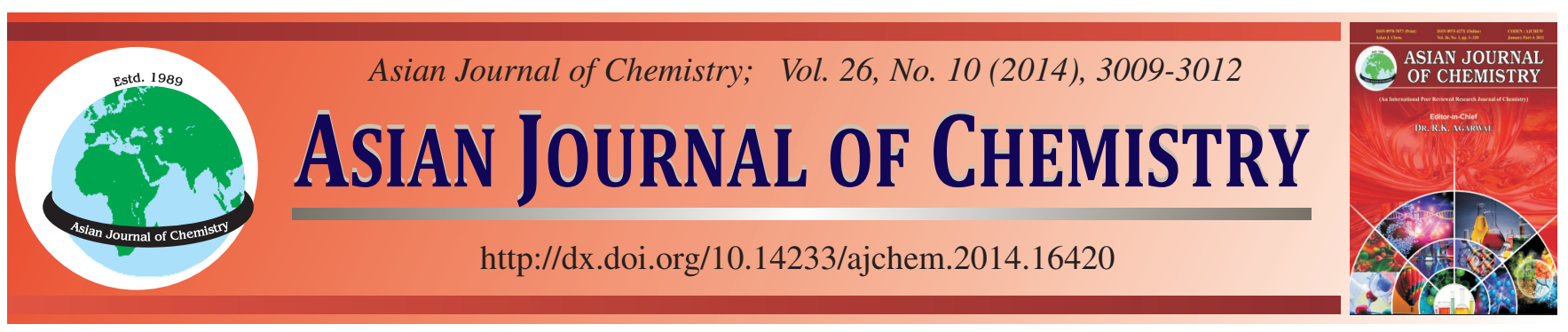

\title{
Extraction of Fatty Acid from Mango Seed Kernel Using Supercritical Carbon Dioxide by Response Surface Methodology
}

\author{
NutTaWAN Yoswathana* and M.N. Eshtiaghi
}

Department of Chemical Engineering, Faculty of Engineering, Mahidol University, Nakornprathom 73170, Thailand

*Corresponding author: Tel: +66 28892138; Ext: 6101; E-mail: nuttawan.yos@mahidol.ac.th

Received: 24 September 2013; $\quad$ Accepted: 14 February 2014; $\quad$ Published online: 10 May 2014;

\begin{abstract}
The extraction of mango seed kernel oil by using innovative extraction and conventional techniques is described. For conventional techniques, maceration and soxhlet were applied by using $95 \%$ ethanol and hexane as solvent. For innovative extraction, the supercritical carbon dioxide $\left(\mathrm{ScCO}_{2}\right)$ as solvent was applied by using response surface methodology. The efficiency yield of extracted oil from soxhlet with $95 \%$ ethanol was the unique technique with $37.1 \%$ yield and the $\mathrm{ScCO}_{2}$ extraction was the lowest technique with $3.13 \%$ yield at 2 $\mathrm{h}$ of extraction time. The fatty acid compositions of mango seed oil from different techniques were similar, but the fatty acid composition of mango seed kernel oil from $\mathrm{ScCO}_{2}$ extraction had greatest total saturated fatty acid with $54.6 \%$ and more highly selective with special of arachidic acid with $11.6 \%$. It is considered that the $\mathrm{ScCO}_{2}$ extraction is competitive with conventional extraction.
\end{abstract}

Keywords: Mango seed kernel, Supercritical carbon dioxide extraction, Fatty acid, Conventional extraction.

\section{INTRODUCTION}

Mangoes are consumed for 572,000 metric tons per year that leads to 57,200 metric tons of mango seeds that need to be eliminated. In Egypt and India, there are many researches about composition in mango seed kernel and their activities. They have found that there are fatty acids and phenolic compounds in mango seed extracted ${ }^{1}$. These composition could be used in many industries such as food preservation, cosmetology and food ingredients ${ }^{2,3}$. Typically, mango seed extraction uses methanol and ethanol as solvent extraction ${ }^{4}$. These solvents cause toxic in extracted substances and resulting in pollutions. Supercritical carbon dioxide extraction has been proposed as nonsolvent residues and better retention of aromatic compounds as an alternative technique to conventional solvent extraction and mechanical pressing for extracting essentential oils $^{5-7}$, seed oil ${ }^{8}$ and carotenoids ${ }^{9}$ from various plant materials. Extracted volatile oil from Aquilaria subnitegra by using supercritical carbon dioxide and hydrodistillation. The maximum yield was reached at $4.43 \%$ from supercritical carbon dioxide at $25 \mathrm{MPa}, 50{ }^{\circ} \mathrm{C}$ and $3 \mathrm{~g} / \mathrm{min}$ of carbodioxide flow rate. Whereas the yield from hydrodistillation process was only $0.23 \%{ }^{10}$. Moreover, extracted patchouli oil by using steam distillation and supercritical carbon dioxide. They have found that maximum yield of patchouli oil was reached $5.07 \%$ at $14 \mathrm{MPa}$ and $40{ }^{\circ} \mathrm{C}$ of supercritical carbon dioxide extraction that more than steam distillation method ${ }^{11}$. So, supercritical fluid could be used to extract herbs and it could extract oil at higher yield than conventional extraction. Furthermore, it could be easily separated from extracted substances ${ }^{12,13}$.

Fatty acid is a carboxylic acid with a long aliphatic chain, which is either saturated or unsaturated. Most naturally occurring fatty acids have a chain of an even number of carbon atoms, from 4 to 28. Fatty acids, especially unsaturated acids, are important as nutritional substances and metabolites in living organisms ${ }^{14}$. Fatty acids that are required by the human body but cannot be made in sufficient quantity from other substrates and therefore must be obtained from food, are called essential fatty acids. Arachidonic acid is one of the essential fatty acids which some part is saturated fatty acid and some part is a polyunsaturated omega- 6 fatty acid 20:4( $\omega-6)$ and presents in the phospholipids of membranes of the body's cells and is abundant in the brain, muscles and liver ${ }^{15,16}$

The response surface methodology is defined as the statistical method that uses quantitative data from appropriate experimental design to reduce number of experimental trials needed to evaluate multiples parameters and their interactions. response surface methodology has been successfully applied for optimizing conditions in food research ${ }^{17,18}$ but very few of extraction of essential oils ${ }^{19}$.

This work was to optimize the conditions, including temperature, pressure and co-solvent for $\mathrm{ScCO}_{2}$ extraction of mango seed kernel oils using response surface methodology. The response variable examined the yields of oil. The fatty acid composition of the oil was also studied under different extraction techniques. 


\section{EXPERIMENTAL}

Mango seeds were procured from the local market. The seeds were washed and cut into two halves. The kernels were removed manually from the seeds and dried in the oven at $60{ }^{\circ} \mathrm{C}$ for $6 \mathrm{~h}$. Then, the mango seed kernels were ground into particles ranging from 0.2 to $0.5 \mathrm{~mm}$ in size by a hammer mill and being forced through a sieve.

Extraction of total oil using maceration: The mango seed kernels (10 and $20 \mathrm{~g}$ ) were added to $150 \mathrm{~mL}$ of hexane for solid to solvent ratio of 1:15 and 2:15 in a $500 \mathrm{~mL}$ flask, respectively and mixed on a magnetic stirrer for 2 to $8 \mathrm{~h}$ at room temperature $\left(28^{\circ} \mathrm{C}\right)$. The supernatant was passed through Whatman filter paper (no. 1). All filtrates were evaporated under vacuum at $60{ }^{\circ} \mathrm{C}$ using a rotary evaporator (Buchi, Switzerland). The volume of sample adjust to $25 \mathrm{~mL}$ using HPLC grade ethanol extracted and stored in refrigerator until gas chromatography (Agilent, model $6890 \mathrm{n}$ ) analysis. The experiments were carried out in triplicate.

Extraction of total oil using Soxhlet: Soxhlet extractions were carried out in triplicate using $20 \mathrm{~g}$ (dry weight) mango seed kernel powder with $300 \mathrm{~mL}$ of $95 \%$ ethanol for 2 to $8 \mathrm{~h}$. Temperature during Soxhlet extraction was set at $70{ }^{\circ} \mathrm{C}$. The extracted oil was evaporated under vacuum at $60{ }^{\circ} \mathrm{C}$ using a rotary evaporator (Buchi, Switzerland). The extracted sample was evaporated and prepared for GC analysis same as Maceration.

Supercritical carbon dioxide $\left(\mathrm{ScCO}_{2}\right)$ extraction using various conditions: The mango seed kernels $(20 \mathrm{~g})$ were filled in a cloth bag and put into the extraction vessel of $\mathrm{ScCO}_{2}$ extractor (SIB, Germany). Response surface methodology was employed to optimize the operating conditions of $\mathrm{ScCO}_{2}$ technique to obtain a high extraction yield. The studied parameters and their concentration ranges were: Pressure $\left(X_{1}\right)$ at 15, 30, $45 \mathrm{MPa}$, temperature $\left(\mathrm{X}_{2}\right)$ at $30,45,60^{\circ} \mathrm{C}$, co-solvent (ethanol) $\left(\mathrm{X}_{3}\right)$ volume $0,10,20 \mathrm{~mL}$. The $\mathrm{CO}_{2}$ flow rate was constant at $2 \mathrm{~kg} / \mathrm{h}$. The oil was collected at the end of the extraction. All the experiments were performed in triplicate and each set of yields was average.

Analysis of fatty acid constituent by gas chromatography: The fatty acid constituents of the total oil yield extracted by the Maceration, Soxhlet and $\mathrm{ScCO}_{2}$ extraction techniques were analyzed to determine the fatty acid profile using gas chromatography (Agilent, model 6890n) analysis with In-house method based on AOAC (2005), 996.06).

\section{RESULTS AND DISCUSSION}

Effect of solid to solvent ration on maceration: The total extracted yield from mango seed kernel using hexane on maceration extraction with different solid to solvent ratios (w/v) (1:15 and 2:15) is shown in Fig. 1.

For material to solvent ratio 1:15, hexane could be developed extractive ability to get more extracted but needed more extraction time that the maximum yield was $21.13 \%$ at $8 \mathrm{~h}$ of extraction time. While the solid to solvent ratio $(2: 15)$ gave $7.89 \%$ at $8 \mathrm{~h}$. It was demonstrated that solid to solvent ratio had a negative effect in extraction by decreasing percent yield. This is consistent with the driving force mass transfer ${ }^{20-23}$ that is the concentration gradient between the solid and the liquid,

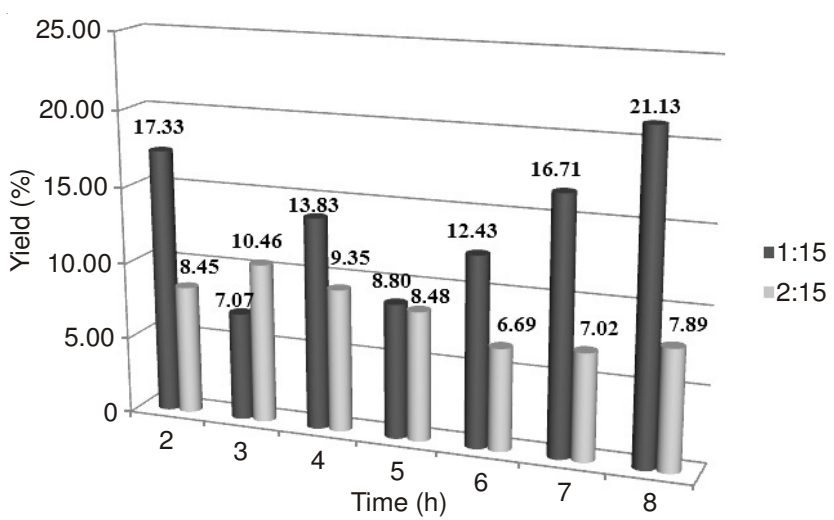

Fig. 1. Influence of solid to solvent ratio (w/v) on the oil yield of hexane maceration

which is greater when a higher solvent to solid ratio is used. Due to the rates of extraction increased with a larger cencentration gradient.

Types of solvent on Soxhlet: The effect of solvent types of solvent on the oil yield using hexane and ethanol which has different the polarity was studied as shown in Fig. 2.

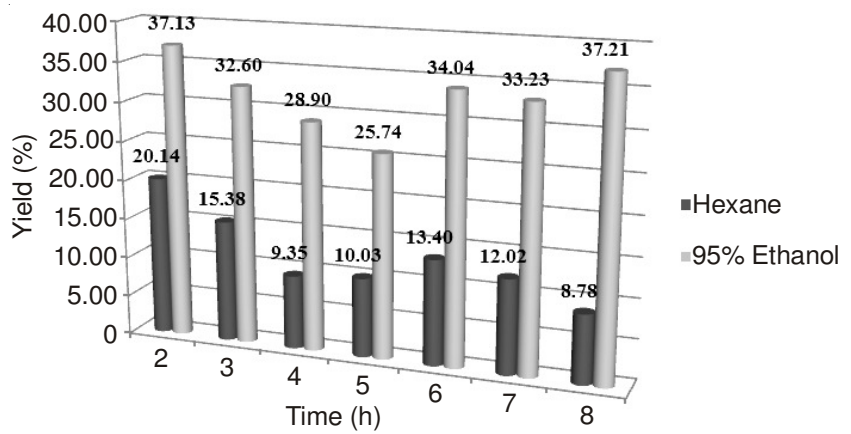

Fig. 2. Effect of solvent on the oil yield of Soxhlet at solid to solvent ratio $(\mathrm{w} / \mathrm{v})$ of $1: 15$

From Fig. 2, $95 \%$ ethanol could extract oil yield much more than marceration and did experiment for $2 \mathrm{~h}$ to get the best yield of $37.13 \%$. While hexane could extract the highest yield only $20.14 \%$ for $2 \mathrm{~h}$ of extraction. According to the fact that the total extract yield kept on increasing with polarity of organic solvent, the oil yield in the extracts of ethanol was higher than that of hexane at all extraction times. Thus, extraction of mango seed kernel using soxhlet could extract for $2 \mathrm{~h}$, due to economy cost of energy and saving times.

Comparison of maceration and Soxhlet techniques: The comparison of maceration and Soxhlet techniques at solid to solvent ratio (w/v) of 1:15 and using $95 \%$ ethanol was investigated the influence of temperature on extraction efficiency yield of mango seed kernel at various times as shown in Fig. 3.

Soxhlet extraction showed the oil yield much more than two times of maceration for all times and used only $2 \mathrm{~h}$ to get the best yield of $37.13 \%$, but maceration could extract highest yield at $12.97 \%$ for $2 \mathrm{~h}$. According to increasing temperature $e^{23,24}$, it helps to enhance both the solubility of solute and the diffusion coefficient. Extraction temperature is affected by the extract mass transfer velocity and the equilibrium concentration. Heating also might soften the plant tissue. Thus, the oil extraction could be developed by increasing temperature. 


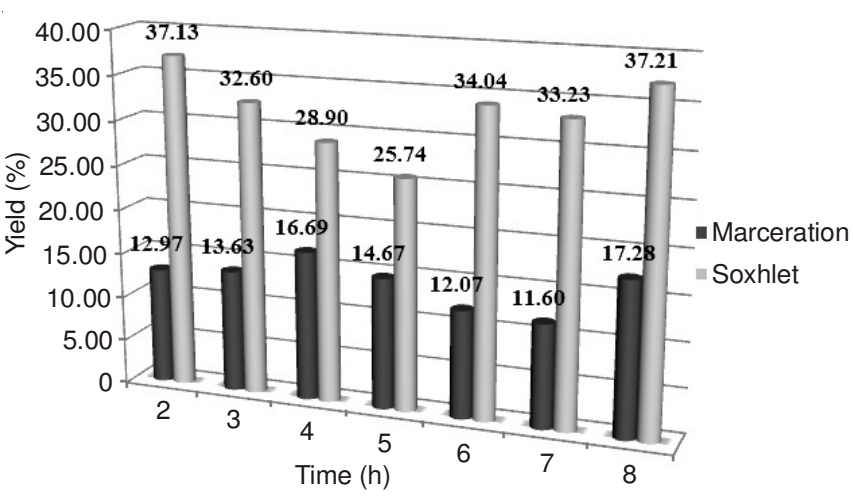

Fig. 3. Comparison of maceration and Soxhlet extractions on efficiency yield

Optimization of important factors for supercritical carbon dioxide $\left(\mathrm{ScCO}_{2}\right)$ extraction by response surface methodology: The experimental values for the oil yields from mango seed kernel were plotted in Figs. 4 to 6 at different combinations of the independent variables as temperature, pressure of extraction and amount of cosolvent (ethanol). The predicted response (Y) using a second-order polynomial model in terms of valuable xi described by eqn. 1 as following:

$$
\begin{aligned}
& Y=5.456-0.082 X_{1}-0.062 X_{2}-0.156 X_{3}+0.001 X_{1} X_{2} \\
& +0.002 \mathrm{X}_{2} \mathrm{X}_{3}+0.03 \mathrm{X}_{1} \mathrm{X}_{3}+1.457 \times 10^{-4} \mathrm{X}_{1}^{2}+3.973 \\
& \times 10^{-5} \mathrm{X}_{2}^{2}-0.001 \mathrm{X}_{3}^{2}
\end{aligned}
$$

where $\mathrm{Y}$ represents the response variables, $\mathrm{X}_{1}, \mathrm{X}_{2}$ and $\mathrm{X}_{3}$ are pressure $(\mathrm{MPa})$, temperature $\left({ }^{\circ} \mathrm{C}\right)$ and amount of ethanol $(\mathrm{mL})$.

The coefficient of determining $\left(\mathrm{R}_{2}\right)$ was 0.912 , indicating adequate accuracy. They showed that the extractable oil content from mango seed kernel increased with increasing temperature (from 30 to $60{ }^{\circ} \mathrm{C}$ ) and pressure at adding ethanol as cosolvent

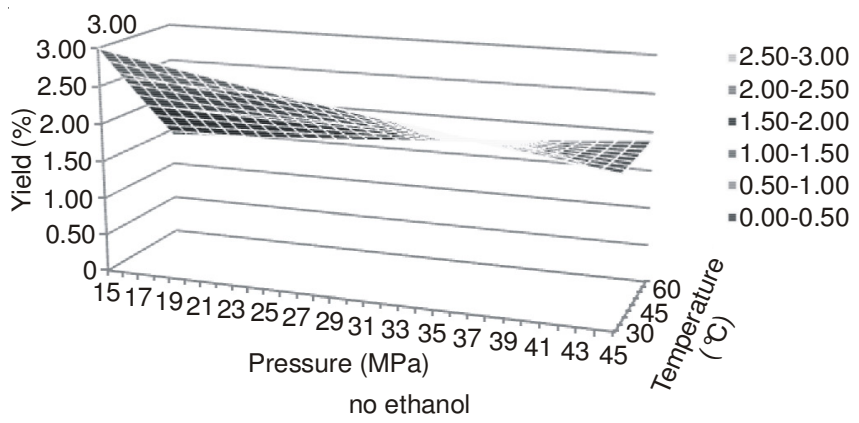

Fig. 4. Per cent oil yield from $\mathrm{ScCO}_{2}$ extraction by response surface methodology (no ethanol)

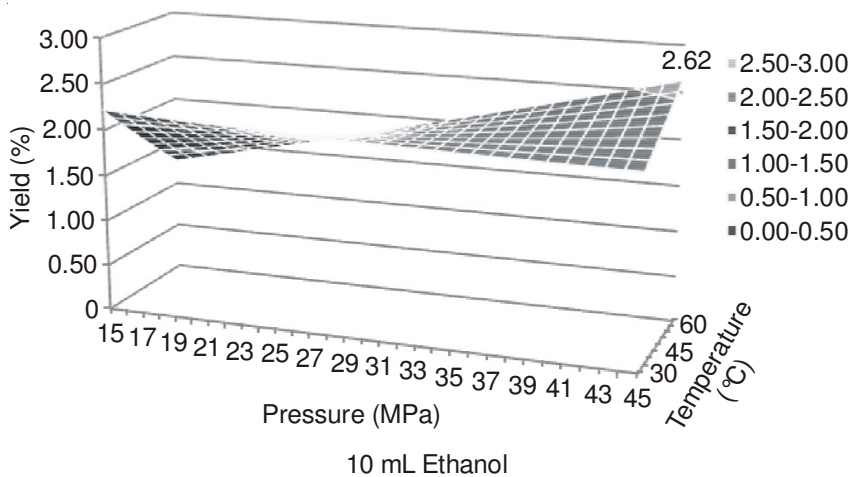

Fig. 5. Per cent oil yield from $\mathrm{ScCO}_{2}$ extraction by response surface methodology with $10 \mathrm{~mL}$ ethanol

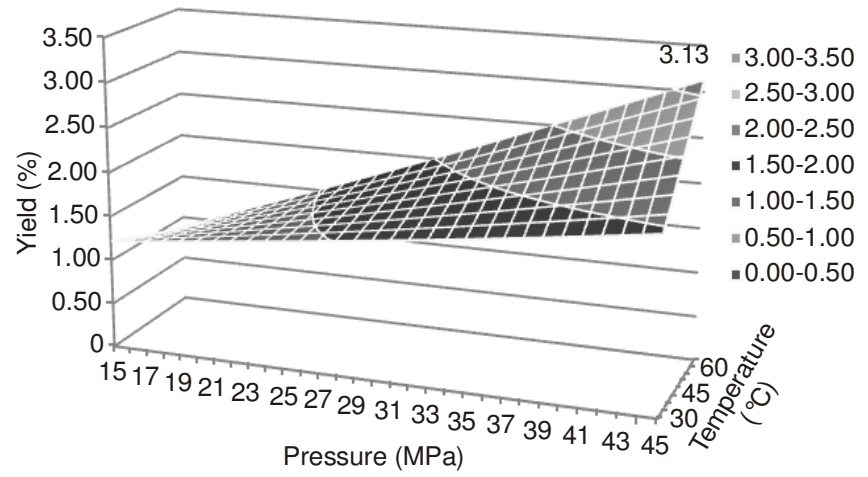

$20 \mathrm{~mL}$ Ethanol

Fig. 6. Oil yield (\%) from $\mathrm{ScCO}_{2}$ extraction by response surface methodology with $20 \mathrm{~mL}$ ethanol

(Figs. 5 and 6). According to the higher pressure of $\mathrm{ScCO}_{2}$ for extraction, the higher of solubility of oil in $\mathrm{ScCO}_{2}$ and ethanol for extraction. Whereas $\mathrm{ScCO}_{2}$ extraction without ethanol viewed the highest extracted oil value at pressure $15 \mathrm{MPa}$ and temperature $60{ }^{\circ} \mathrm{C}$ (Fig. 4). This occurrence might be due to decomposed characteristic of oil. Also, pressure and temperature have a significant effect of oil yield extraction from mango seed kernel and effects of pressure depend on ethanol content in $\mathrm{ScCO}_{2}$ extraction. Because it may cause of moisture content that block $\mathrm{ScCO}_{2}$ (non-polar) to get into the material bed. From eqn. 1, the highest oil yield was $3.13 \%$ at pressure $45 \mathrm{MPa}$, temperature $60{ }^{\circ} \mathrm{C}$ and using $20 \mathrm{~mL}$ of $95 \%$ ethanol at $2 \mathrm{~h}$ extraction time as shown in Fig. 6.

Fatty acid compositions in mango seed kernel oil: The

\begin{tabular}{|c|c|c|c|c|c|}
\hline \multicolumn{6}{|c|}{$\begin{array}{c}\text { TABLE-1 } \\
\text { FATTY ACID COMPOSITIONS OF MANGO } \\
\text { SEED KERNEL FROM VARIOUS EXTRACTIONS }\end{array}$} \\
\hline \multirow{3}{*}{ Fatty acid } & \multicolumn{5}{|c|}{ Percent oil in sample } \\
\hline & \multicolumn{2}{|c|}{ Marceration } & \multicolumn{2}{|c|}{ Soxhlet } & \multirow{2}{*}{$\begin{array}{l}\text { Super- } \\
\text { critical } \\
\mathrm{CO}_{2} \\
\end{array}$} \\
\hline & Hexane & Ethanol & Hexane & Ethanol & \\
\hline Lauric acid (C12:0) & 0.06 & 0.08 & 0.10 & 0.10 & 0.32 \\
\hline Myristic acid (C14:0) & 0.13 & 0.16 & 0.12 & 0.15 & 0.28 \\
\hline Pentadecanoic acid (C15:0) & 0.04 & 0.05 & 0.05 & 0.06 & - \\
\hline Palmitic acid (C16:0) & 9.45 & 9.63 & 9.21 & 8.98 & 7.36 \\
\hline Heptadecanoic acid (C17:0) & 0.17 & 0.17 & 0.19 & 0.19 & - \\
\hline Stearic acid (C18:0) & 37.30 & 33.90 & 36.03 & 35.19 & 33.20 \\
\hline Arachidic acid (C20:0) & 1.99 & 1.96 & 1.96 & 1.74 & 11.63 \\
\hline Behenic acid (C22:0) & 0.49 & 0.54 & 0.47 & 0.51 & 1.31 \\
\hline Tricosanoic acid (C23:0) & 0.09 & 0.13 & 0.09 & - & - \\
\hline Lignoceric acid (C24:0) & 0.44 & 0.49 & 0.47 & 0.44 & 0.49 \\
\hline Total saturated fat & 50.16 & 47.11 & 48.69 & 47.36 & 54.59 \\
\hline cis-9-Oleic acid $(\mathrm{C} 18: \ln 9 \mathrm{c})$ & 42.08 & 42.95 & 43.16 & 43.06 & 38.74 \\
\hline $\begin{array}{l}\text { cis-11-Eicosenoic acid } \\
\text { (C20:1n11) }\end{array}$ & 0.20 & 0.22 & 0.22 & 0.18 & 0.85 \\
\hline $\begin{array}{l}\text { Total monounsaturated fatty } \\
\text { acid }\end{array}$ & 42.28 & 43.17 & 43.38 & 43.24 & 39.59 \\
\hline $\begin{array}{l}\text { cis-9,12-Linoleic acid } \\
(\mathrm{C} 18: 2 \mathrm{n} 6)\end{array}$ & 6.62 & 8.42 & 6.89 & 8.07 & 5.04 \\
\hline$\alpha$-Linoleic acid (C18:3n3) & 0.89 & 1.30 & 1.05 & 1.32 & 0.78 \\
\hline $\begin{array}{l}\text { cis-11,14-Eicosadienoic acid } \\
\text { (C20:2) }\end{array}$ & 0.05 & - & - & - & - \\
\hline $\begin{array}{l}\text { Total polyunsaturated fatty } \\
\text { acid }\end{array}$ & 7.56 & 9.72 & 7.94 & 9.39 & 5.82 \\
\hline Total unsaturated fat & 49.84 & 52.89 & 51.32 & 52.63 & 45.41 \\
\hline
\end{tabular}
analysis of fatty acid obtained from mango seed kernel that revealed the presence of fifteen compounds in Table-1. The 
results demonstrated that the quantities of fatty acids were no significant differences between the mango seed kernel oils extracted by $\mathrm{ScCO}_{2}$ and conventional techniques. However the quality of $\mathrm{ScCO}_{2}$ extracted oil was obtained the saturated fatty acid groups higher than convention techniques and much more amount of arachidic acid which is an essential fatty acid. Table-1. Fatty acid compositions of mango seed kernel from various extractions.

\section{Conclusion}

For mango seed kernel oil extraction, Soxhlet with $95 \%$ ethanol as solvent was the efficient extraction to get extracted oil $37.13 \%$ at the solid to solvent ratio of $1: 15$ and $2 \mathrm{~h}$ extraction time. Hence the amount of matter yield by using organic solvents will be always higher than that by using supercritical fluids. The $\mathrm{ScCO}_{2}$ extraction causes a fractionation of the oil by depressurization, which permits the production of various grades of oil with different fatty acid contents and no needed to recover solvent as conventional techniques. The independent parameters of $\mathrm{ScCO}_{2}$ extraction was temperature, while effect of pressure depended on the amount of cosolvent. Thus $\mathrm{ScCO}_{2}$ extraction is attractive method to extract fatty acid in mango seed kernel.

\section{ACKNOWLEDGEMENTS}

The authors thank the Thai Research Council of Thailand (NRCT) for financial support. Thanks are also due to Faculty of Engineering, Mahidol University for supported equipment and research place.

\section{REFERENCES}

1. A.E.M. Abdalla, S.M. Darwish, E.H.E. Ayad and R.M. El-Hamahmy, Food Chem., 103, 1141 (2007).
2. S. Kittiphoom, Int. Food Res. J., 19, 1325 (2012).

3. S. Kittiphoom and S. Sutasinee, Int. Food Res. J., 20, 1145 (2012).

4. A. Abdalla, S. Darwish, E. Ayad and R.M. El-Hamahmy, Food Chem., 103, 1134 (2007).

5. M. Herrero, A. Cifuentes and E. Ibanez, Food Chem., 98, 136 (2006).

6. A. Caredda, B. Marongiu, S. Porcedda and C. Soro, J. Agric. Food Chem., 50, 1492 (2002).

7. W. Guan, S. Li, R. Yan, S. Tang and C. Quan, Food Chem., 101, 1558 (2007).

8. W.Y. Lee, Y.J. Cho, S.L. Oh, J.H. Park, W.S. Cha and J.Y. Jung, J. Food Sci. Biotechnol., 9, 174 (2000).

9. M. Sun and F. Temelli, J. Supercrit. Fluids, 37, 397 (2006).

10. R. Thanyaporn, T. Supawan and N. Somkiat, Food Bioprod. Process., 80, 43 (2009).

11. A. Donelian, L.H.C. Carlson, T.J. Lopes and R.A.F. Machado, J. Supercrit. Fluids, 48, 15 (2009).

12. N. SaeLee, Thailand, J. Pharmacy, 15-20 (2005).

13. X. Xu, J. Dong, X. Mu and L. Sun, J. Food Bioprod. Process., 89, 47 (2011).

14. X. Zhao, H. Wang, J. You, Y. Suo and J. Sun, J. Anal. Chem., 34, 150 (2006).

15. J.M. Valle and E.L. Uquiche, J. Am. Oil Chem. Soc., 79, 1261 (2002).

16. J.M. del Valle, O. Rivera, M. Mattea, L. Ruetsch, J. Daghero and A. Flores, J. Supercrit. Fluids, 31, 159 (2004).

17. S. Ibanoglu and P. Ainsworth, J. Food Eng., 64, 243 (2004).

18. A.I. Varnalis, J.G. Brennan, D.B. MacDougall and S.G. Gilmour, J. Food Eng., 61, 153 (2004).

19. S. Sonsuzer, S. Sahin and L. Yilmaz, J. Supercrit. Fluids, 30, 189 (2004).

20. J.- Zhang, X.- Hou, T. Yu, Y. Li and H.- Dong, J. Integr. Agric., 11, 151 (2012).

21. J.E. Cacace and G. Mazza, J. Food Eng., 59, 379 (2003).

22. M. Pinelo, M. Rubilar, M. Jerez, J. Sineiro and M.J. Nunez, J. Agric. Food Chem., 53, 2111 (2005).

23. N. Durling, O. Catchpole, J. Grey, R. Webby, K. Mitchell, L. Foo and N. Perry, J. Food Chem., 101, 1417 (2007).

24. J. Shi, J. Yu, J. Pohorly, C. Young, M. Bryan and Y. Wu, J. Food Agric. Environ., 1, 42 (2003). 